\title{
Autoregressive Distributed Lag Kurs Dan Ekspor Karet Remah Terhadap Pertumbuhan Ekonomi Indonesia
}

\author{
Nulhanuddin ${ }^{* a}$,Devi Andriyani ${ }^{* b}$ \\ *Fakultas Ekonomi dan Bisnis Universitas Malikussaleh \\ a Corresponding author: nulhanhasibuan56@gmail.com \\ bdevisep80@gmail.com
}

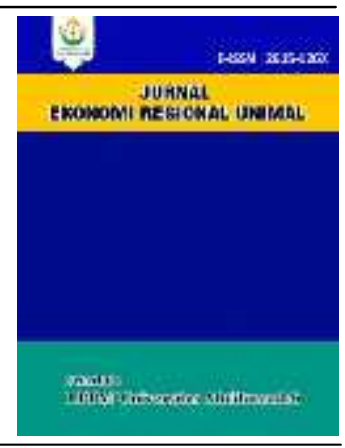

A R T I C L E I N F O R M A T I O NA B S T R A C T

Keywords:

economic growth, exchange rates, exports and the ARDL approach.
This study aims to determine the effect of short-term and long-term exchange rates and crumb rubber exports on the economic growth of Indonesia. The data used are secondary data for 39 years from 1980 to 2018 accessed on www.world.bank.wdi.data.bank.org, www.pertanian.go.id, www.bps.go.id, and www.bps.go.id. The data analysis method used is the Autoregressive Distributed Lag (ARDL) approach with the help of EViews 10 software. The results show that the economic growth is stationary at the level and exchange rate and exports of stationary crumb rubber at the first difference level and have cointegration in the long-term relationship. The test results in the shortterm analysis of the exchange rate have a positive and significant effect, and exports have a positive but insignificant effect on economic growth, while in the long run, the exchange rate has a negative effect but insignificant, and exports have a positive but insignificant effect on the economic growth of Indonesia.

\section{PENDAHULUAN}

Indonesiamerupakan negara yang menganut sistem perekonomian terbuka, yaitu sangat mengandalkan pada kegiatan perdagangan internasional dalam membantu meningkatkan pertumbuhan perekonomian(Wikipedia, 2019). Selain itu kegiatan perdagangan internasional juga sangat penting untuk memacu industri dalam negeri untuk berkembang dan tumbuh, dalam perdagangan internasional suatu negara juga menerapkan yang namanya devaluasi kurs mata uang, dikarenakan devaluasi kurs sangat berpengaruh terhadap lancar atau tidak suatu perdagangan internasional yang diterapkan suatu negara.

Devaluasi kurs merupakan suatu bentuk kebijakan oleh pemerintah agar menurunkan nilai kurs lokal terhadap nilai kurs asing, kurs adalah nilai tukar suatu mata uang kepada mata uang lain untuk melakukan suatu transaksi pembayaran dan kurspada dasarnya dapat dijadikan sebagai perbandingan

keadaan

suatu
perekonomiannegara(Yahya et al., 2015). Proses perkembangan nilai tukar kearah yang lebih baik dapat menunjukkan bahwa perekonomian suatu negara memiliki efek yang lebih teraturdan stabil(Salvatore, 2008), sebaliknya jika pertumbuhan nilai mata uang yangrelatif kurang stabil dapat menunjukkan bahwa negara tersebut bisa dikategorikankedalam negara dengan kondisi perekonomian yang tidak stabil. Krisis keuanganAsia ini disebabkan oleh banyak faktor, baik yang bersifat non ekonomi maupunekonomi.

Faktorbukanekonomi lebih sering diasumsikan sebagai penyebab naik turunnyanilai tukar terhadap dolar. Untuk mengidentifikasinya, bahkan menaksiran seberapabesar pengaruh bukan ekonomi tersebut akan sangat sukar dilakukan diantaranyatidak jelasnya arah akan perubahan politik, maka info tentang pemerintahan otomatistumbuh menjadi persoalan ekonomi juga. Banyak sumber daya alam seperti di bidang perkebunan contohnya karet alam yaitu merupakan salah satu komoditi perkebunan yang memegang 
peranan penting sebagai penymbang devisa negara terbesar kedua bidang perkebunan setelah sawit karena merupakan satu diantara komoditas ekspor non migas yang memberikan kontribusi yang besar (Kartikasari, 2017).

Berikut adalah data kurs, ekspor karet remah dan pertumbuhan ekonomiIndonesia :

\section{Tabel 1}

Data kurs, ekspor karet remah dan pertumbuhan ekonomiIndonesia

\begin{tabular}{|c|c|c|c|}
\hline Tahun & $\begin{array}{c}\text { Kurs Dolar } \\
\text { Amerika Serikat } \\
\text { (Rp) }\end{array}$ & $\begin{array}{c}\text { Ekspor Karet } \\
\text { remah } \\
\text { (Juta USD) }\end{array}$ & $\begin{array}{l}\text { Pertumbuhas } \\
\text { Ekonomi }(\%)\end{array}$ \\
\hline 2015 & 13.795 & $3.564: 1$ & 5,20 \\
\hline 2016 & 13.4 .6 & $3.243,0$ & 5,02 \\
\hline 2017 & 13.548 & $4.958,3$ & $5,0 ?$ \\
\hline 2018 & 14.710 & 3.836 .7 & $5,1 ?$ \\
\hline
\end{tabular}

Sumber: BPS Indonesia, Tahun 2019

Berdasarkan pada Tabel 1.1 di atas, data kurs dan data pertumbuhan ekonomibanyak mengalami fluktuaktif.Dimana di tahun 2016 nilai kurs menguat dari Rp13.795 per USD1 menjadi Rp13.436 per USD1 tapi pertumbuhan ekonomi malah melemah dari 5,20 persen menjadi 5,02 persen.

Tahun 2017 dan 2018 kurs mengalami penurunan atau melemah yaitu di tahun 2017 kurs melemah dari Rp13.436 per USD1 menjadi Rp13.548 per USD1 tetapi pertumbuhan ekonomi Indonesia malah menguat yang dari 5,02 persen menjadi 5.07 persen walaupun peningkatan pertumbuhan ekonomi peningkatannya hanya sedikit yaitu 0,05 persen dan juga di tahun 2018 juga mengalami hal yang sama yaitu kurs melemah menjadi Rp14.710 per USD1 tapi pertumbuhan ekonomi Indonesia malah menguat menjadi 5,17 persen. Fenomena tersebut bertentangan dengan teori ekonomi, Menurut (Nasution, 2009) tingkat nilai tukar atau kurs berkorelasi positif dengan pertumbuhan ekonomi. Secara sederhana, nilai tukar yang kuat secara sistematis akan meningkatkan sentra perekonomian yang lebih baik, jika perekonomian semakin baik maka pertumbuhan ekonomi juga akan membaik dan apabila nilai tukar melemah akan mengakibatkan tingkat efisiensi perekonomian menurun. Nilai mata uang yang kuat dan stabil akan meningkatkan investasi dalam suatu negara dan juga mempengaruhi peningkatan pergerakan ekonomi yang stabil dan kuat (Tang, 2015).

Hubungan antara ekspor karet remah dengan pertumbuhan ekonomi mengalami permasalahan di tahun 2018 nilai ekspor karet remah menurun dari USD4.958,3 juta menjadi USD3.836,7 juta tetapi pertumbuhan ekonomi Indonesia malah menguat dari 5.07 persen menjadi 5,17 persen, hal tersebut bertentangan dengan teori yang dikemukakan oleh (Sutawijaya, 2010)yaitu jika peningkatan ekspor cenderung bergerak meningkat maka akan dapat mengakibatkan sektor sektor ekonomi tumbuh, dengan sektor sektor ekonomi tumbuh akan mengakibatkan laju perekonomian meningkat yang secara otomatis meningkatkan pertumbuhan ekonomi juga. Semakin banyak transaksi yang dihasilkan dari ekspor, semakin tinggi bursa asing yang masuk akan mengakibatkan pertumbuhan ekonomi yang lebih baik, Oleh karena itu, perlu untuk menganalisis faktor-faktor yang mempengaruhi peningkatan ekspor untuk memenuhi kebutuhan konsumsi(Yahya et al., 2015).

Penelitian ini bertujuan untuk mengetahui Mengetahui Seberapa besarkah pengaruh jangka panjang dan jangka pendek antara kurs dengan pertumbuhan ekonomi Indonesia danmengetahui Seberapa besarkah pengaruh jangka panjang dan jangka pendek ekspor karet remah dengan pertumbuhan ekonomi Indonesia.

Selanjutnya bagian kedua dari penelitian ini akan membahas tinjauan teoritis, metode penelitian akan dibahas pada bagian ketiga. Kemudian pada bagian ke empat akan dibahas hasil penelitian dan pembahasan. Pada bagian kelima akan membahas kesimpulan dan saran.

\section{TINJAUAN TEORITIS Pertumbuhan Ekonomi}

Pertumbuhan ekonomi adalah suatu perkembangan kegiatan dalam aktivitas perekonomian yang menyebakan bertambahnya produksi barang serta jasa serta meningkatnya kemakmuran disuatu negara. Tingginya pertumbuhan ekonomi serta berkelanjutan salah 
satu syaratuntuk berlangsungnya pembangunan akan ekonomi (Sukirno, 2000).

Pertumbuhan ekonomi adalah kenaikan rata-rata dari output yang dihasilkan setiap orang dalam memproduksi barang ataupun jasa dan merupakan tingkat pertumbuhan perkapita secara rill bagi setiapindividu. Dengan peningkatan ini akan diharapkan dapat meningkatkan capital, produksi setiap para pekerja atau dengan arti lain meningkatkan cadangan devisa. Selain akan $\mathrm{Hl}$ itu pertumbuhan ekonomi dapat disebut juga sebagai kenaikan GDP (gross domestik product) rill sebuah negara pada tahun tertentu yang memperlihatkan naiknya pendapatan perakita setiap individu dalam perekonomian dan dalam sebuah negara pada tahun tertentu (Mankiw, 2003).

pertumbuhan ekonomi merupakan sasaran yang ingin diraih oleh perekonomian riil. Jadi perekonomian disebut naik atau mulai berkembang bila terjadi akan pertumbuhan output riil. Output dari total riil suatu perekonomian bisa akan tetap stabil atau mengalami penurunan disepanjang waktu. Perubahan ekonomi merangkup baik pertumbuhan, statis maupun stagnasi pendapatan nasional riil. Penurunan merupakan perubahan yang negatif, sedangkan peningkatan adalah tujuan dalam jangka panjang, dan seoftimal mungkin tetap dengan pertumbuhan ekonomi dalam jangka pendek.

\section{Kurs}

Menurut(Adiningsih et al., 2002)nilai tukar rupiah adalah harga nilairupiah kepada mata uang negara lainnya. Jadi, nilai tukar uangrupiah merupakan nilai dari suatu mata uang rupiah yang diubah atau tranlasikan ke dalam mata uang negara lain. Misalnya; nilai tukar rupiah terhadap Dolar AS, nilai tukar rupiah terhadap Yen, dan mata uang lainnya.

Kurs merupakan salah satu nilai yang krusial dalam perekonomian terbuka mengingat pengaruhnya yang sedemikian besar terhadap neraca transaksi berjalan maupun variabelvariabel makro ekonomi yang lain. Ada dua pendekatan yang dipakai untuk memenuhi nilai tukar mata suatu uang yang pendekatan moneter dan pendekatan pasar. Dalam pendekatan moneter, nilai tukar mata uang di diartikan sebagai harga dikarenakan mata uang asing diperjual belikan terhadap mata uang dalam negeri dan harga tersebut bersinggungan dengan penawaran dan permintaan uang(Kasmir, 2008).

Nilai tukar yang stabil diperlukanagar tercapainya keadaan usaha yang lebih baik bagi peningkatan dunia perniagaan. Untuk menjaga kestabilan nilai tukar, bank sentral pada sewaktu tertentu melakukan intervensi di pasar-pasar valuta asing, terkhususnya pada saat terjadinya goncangan yang berlebihan. Nilai tukar dipengaruhi beberapa faktor lainnya seperti tingkat suku bunga dalam negeri, tingkat inflasi, dan intervensi bank sentral terhadap pasar uang(Kasmir, 2008).

\section{Ekspor}

Ekspor adalah suatu kegiatan yang mengeluarkan barang dan jasa dari suatu negara ke pasar internasional atau ke negara lain. Menurut (Sukirno, 2000) ekspor adalah pembelian produk domestik oleh Negara asing akan barang yang dibuat perusahaan-perusahaan di Indonesia. Ekspormempunyai arti sebagai pengiriman dan penjualan barang-barang dari dalam negeri ke luar negeri. Terjadinya kegiatan ekspor dikarenakankecukupan akan barang dan jasa sudah terpenuhi di dalam negeri atau karena barang dan jasa tersebut memilliki daya saing yang tinggi baik dalam harga ataupun mutu produk sejenis di pasar internasional. Bagi kebanyakanNegara-negara termasuk Indonesia, perdagangan internasional, khususnya ekspor, mempunyai andil yang penting, yakni sebagai alat penggerak perekonomian domestik. Ekspor menghasilkan devisa, selanjutnya akan digunakan untuk pembiayaan impor dan pembangunan sektor-sektor ekonomi didalam negeri. Karena itu, secara teoritis (hipotesis) dapat dikatakan bahwa ada korelasi positif antara ekspor, cadangan devisa dan pertumbuhan ekonomi (Tambunan, 2003).

ekspor merupakan kegiatan perdagangan internasional dengan mengirim barang atau produk ke luar negeri dikarenakan kebutuhan akan produk tersebut sudah terpenuhi di dalam negeri itu sendiri atau barang itu memiliki daya saing harga maupun kualitas mutu di pasar internasional, ekspor merupakan salah satu penyumbang devisa ataupun 
pendapatan negara terbesar di indonesia dan merupakan faktor penting dalam pembangunan negara, dan dari kegiatan ekspor itu dapat meningkatkan laju perekonomian negara dan pendapatan dari kegiatan ekspor itu dapat juga digunakan untuk membiayai pembelian jasa atau barang barang impor.

\section{Kerangka Konseptual}

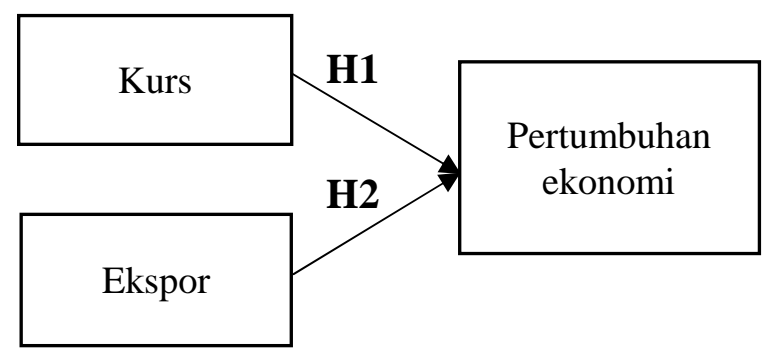

Gambar 1.

\section{Kerangka Konseptual}

Kerangka konseptual gambar 1 di atas menjelaskan pengaruh antara variabel bebas dan variabel terikat, yaitu pengaruh kurs dan ekspor terhadappertumbuhan ekonomi Indonesiayang akan di dengan mengguakan uji alat regressi dinamis yaitu menggunakan model Autoregressive Distributed Lag (ARDL)untuk melihat hubungan jangka panjang dan jangka pendek variabel penelitian tersebut.

\section{Hipotesis}

Adapun hipotesis alternatif yang diberikan dalam penelitian ini adalah sebagai berikut :

$\mathrm{H}_{1}$ : Diduga kursberpengaruh dalam jangka panjang dan jangka pendek terhadap pertumbuhan ekonomi Indonesia.

$\mathrm{H}_{2}$ : Diduga Ekspor karet remahberpengaruh dalam jangka panjang dan jangka pendek terhadap pertumbuhan ekonomi Indonesia.

\section{METODEPENELITIAN}

\section{Data dan Sumber Data}

Jenis penelitian yang dipakai dalam penelitian ini adalah penelitian kuantitatif, dimana data yang diperoleh ditampilkan dalam bentuk angka dan analisis menggunakan metode statistika dan ekonometrika. Penelitian ini menggukan data runtut waktu (time series). Data time series adalah data yang secara kronologis disusun berdasarkan waktu digunakan untuk melihat pengaruh dalam rentang waktu tertentu (Kuncoro, 2007).

Jumlah observasi adalah sebanyak 39 observasi, yaitu dari tahun 1980-2018. Kurs, Ekspor Karet remah dan pertumbuhan ekonomi di Indonesia yang mengalami fluktuaktif dari tahun 1980-2018. Adapun data yang di gunakan peneliti adalah kurs, ekspor karet remah dan pertumbuhan ekonomi yang bersumber dari badan pusat statistik (BPS) Republik Indonesia, World Bank, Kementerian Pertanian Republik Indonesia, SEKI (Statistik Ekonomi Keuangan Indonesia)Bank Indonesia dan sumber-sumber yang lainnya.

\section{Definisi Operasionalisasi Variabel}

Operasionalisasi variabel merupakan
petunjuk bagaimana variabel-variabeldalam penelitian diukur. Untuk menerangkan dan mempermudah pengertian terhadap variabelvariabel yang akan dianalisis dalam penelitian ini, maka butuh dirumuskan operasionalisasi variabel yaitu sebagai berikut:

Variabel terikat (variabel dependen) juga sering disebut variabel output, kriteria, konsekuen. Dalam bahasa Indonesia sering disebut sebagai variabel terikat. Variabel terikat merupakan variabel yang menjadi akibat atau yang menjadi dipengaruhi, karena keberadaan variabel bebas (Sugiyono, 2012).

Variabel terikat atau dependen dalam penelitian ini adalah Pertumbuhan Ekonomi yaitu proses perubahan perekonomian negara Indonesia dengan menggunakan satuan persen dalam penelitian ini periode 1980-2018.

Variabel bebas (variabel independen) juga sering di sebut variabel stimulus, prediktor, antecedent. Dalam bahasa Indonesia disebut variabel bebas. Variabel bebas merupakan variabel yang mempengaruhi atau yang menjadi sebab perubahannya atau timbulnya variabel terikat (Sugiyono, 2012).

Variabel independen dalam penelitian ini adalah:

1. Kurs, yaitu perubahan kurs dollar amerika serikat terhadap kurs rupiah dengan 
menggunakan satuan Rupiah dari tahun 1980-2018.

2. Ekspor, yaitu total seluruh ekspor karet alam remah Indonesia dengan menggunakan satuan Dollar Amerika Serikat dari tahun 1980-2018.

\section{Metode Analisis Data}

Untuk melihat pengaruh hubungan kurs dan ekspor karetremahterhadap pertumbuhan ekonomi Indonesia dari tahun 1980-2018 dianalisis dengan menggunakan model ARDL (Autoregressive Distributed Lag).model ARDL (Autoregressive Distributed Lag) merupakan gabungan antara model AR (Auto Regressive) dan DL (Distributed Lag). Model AR adalah model yang menggunakan satu maupun lebih dari lebih data masa lampau dari variabel terikat. Sedangkan model DL adalah merupakan regresi mengkaitkan data pada waktu sekarang dan waktu masa yang lalu (lagged) dari variabel bebas(Gujarati \& Porter, 2009). Dalam penelitian ini penulis menggunakan model ARDL dimana dapat diartikan sebagai sebuah model yang menggunakan waktu data pada waktu masa lampau dan masa sekarang yang terdiri dari variabel bebas dan variabel terikatnya.

ARDL (Autoregressive Distributed Lag) adalah model alat analisis dalam ekonometrika. Model ini yaitu suaatu model regresi linier yang memperhitungkan pengaruh waktu jangka panjang dan jangka pendek akan variabel terikat terhadap suatu unit perubahan didalam hasil nilai variabel penjelas(Gujarati, 2012). Ada beberapa keunggulan dari model ARDL (Auto Regressive Distributed Lag) antara lain:

- ARDL tidak mementingkan tingkat stasioner dan tingkat integrasi. Maksudnya ARDL masih bisa digunakan walaupuntiap-tiap variabel berada pada tingkat stasioneritas yang berbeda baik itu pada kategori level, first difference, dan second difference.

- Penggunaan model ARDL juga tidak juga haris stasioner pada ordo yang sama. Modelnya ARDL tetap dapat digunakan meskipun variabel dengan ordo integrasinya berbeda-beda.
- Model ARDL tidak mempermasalahkan jumlah data yang hanya beberapa data, sedangkan pada pengujian yang lain jumlah data yang banyak adalah menjadi suatuprasyarat utama dalam penelitian.

- ARDL digunakan juga untuk menguju kesimultanan hubungan jangka panjang dan jangka pendek diantara variabel time series.

Dalam estimasi ARDL, untuk melihat apakah variabel $\mathrm{Y}$ mempengaruhi $\mathrm{X}$ dan demikian pula sebaliknya, dapat diketahui dengan cara membandingkan nilai t-tabel. Jika nilai t-statistik lebih besar pada nilai t-tabel, maka dapat dikatakan bahwa variabel $\mathrm{Y}$ mempengaruhi $\mathrm{X}$.

\section{Uji Stasioneritas}

Untuk menghindari masalah regresi lancung ini maka yang harus dilakukan adalah mengubah data nonstasioner menjadi data stasioner(Widarjono, 2007).Uji stasioner dapat dilakukan dengan uji akar-akar unit (Unit Root Test) untuk menetukan stasionernya suatu variabel.Jika ternyata belum stasioner juga maka harus dilanjutkan melalui uji derajat integrasi (integration test).Pada penelitian ini digunakan uji unit root test dengan Philips-Perron(PP).

Hipotesis dari uji stasioner data adalah :

$\mathrm{H}_{0}=$ Data terdapat unit root (data tidak stasioner)

$\mathrm{H}_{1}=$ Data tidak terdapat unit root (datastasioner)

Jika nilai dari $|t|>$ nilai mutlak dari nilai kritik Mackinnon, maka tolak $\mathrm{H}_{0}$. Artinya data tidak terdapat unit root (data stasioner) atau dapat juga membandingkan $p$-value dengan nilai $\alpha$, jika $p$-value < nilai $\alpha$ maka tolak $\mathrm{H}_{0}$ artinya data tersebut stasioner karena tidak mengandung unit root.

\section{Penentuan Lag Optimum}

Penetapan lag optimal pada model dilakukan untuk mengetahui kombinasi lag pada model ARDL. Penentuan lag optimal sangat penting dalam model ARDL, karena suatu variabel juga dipengaruhi oleh variabel itu sendiri, selain dipengaruhi oleh variabel lain. Menurut(Nizar, 2012)penentuan panjang lag itu digunakan untuk mengetahui lamanya periode atau respon suatu 
variabel terhadap variabel masa lampaunya dan terhadap variabel endogen lainnya. Dalam penelitian ini untuk menentukan panjang lag optimal akan menggunakan kriteria Likehood Ratio (LR), Final Prediction erroe (FPE), Akaike Information Criterion (AIC), Schwartz Information Criterion (SIC), Hanna-Quinn Information Criterion (HQ).

Penentuan lag optimal dengan menggunakan syarat informasi data diperoleh dengan mempunyai tanda bintang paling terbanyak diantara lag yang diperoleh. Model ARDL itu diestimasi dengan tingkat lag yang berbeda dan selanjutnya tanda bintang ter banyak akan digunakan sebagai nilai lag yang paling optimum.

\section{Uji Kausalitas Granger}

Setelah melakukan pengujian lag optimum tahapan selanjutnya adalah melakukan uji kausalitas yang digunakan untuk mengetahui hubungan saling mempengaruhi antara variabel independen. Uji kausalitas melihatakan pengaruh masa lalu terhadap kondisi saat sekarang.

Uji kausalitas granger ini pada awalnya mengasumsikan akan informasi yang akurat untuk memprediksi variabel bebas dan terikat adalah hanya ada pada kedua data runrut waktu dari kedua variabel tersebut. Untuk menguji secara lebih empiris hipotesis ini menggunakan kausalitas granger antara dua variabel atau lebih. Uji Kausalitas Granger merupakan sebuah metode mengetahui dimana suatu variabel terikat dapat dipengaruhi oleh variabel lainnya (variabel bebas)dan sisi lain variabel bebas tersebut dapat menempati posisi varabel terikat. Hubungan seperti ini disebut kausalitas atau dua arah .

\section{Uji Kointegrasi Bound Test}

Uji kointegrasi dilakukan untuk menguji apakah variabel-variabel yang tidak stasioner pada data level terkointegrasi antara satu variabel dengan variabel yang lain. Kointegrasi ini terbentuk apabila kombinasi antara variabelvariabel yang tidak stasioner menghasilkan variabel yang stasioner. Apabila terdapat persamaan sebagai berikut:

$\mathrm{y}_{\mathrm{t}}=\beta_{0}+\beta_{1} \mathrm{x}_{1}+\mathrm{e}_{\mathrm{t}}$
Maka, error dari persamaan tersebut dapat ditulis menjadi:

$\mathrm{e}_{\mathrm{t}}=\mathrm{y}_{\mathrm{t}}-\beta_{0}-\beta_{1} \mathrm{x}_{1}$

dengan catatan bahwa $e_{t}$ merupakan kombinasi linear dari kurs dan ekspor.

Konsep kointegrasi yang diperkenalkan oleh Engle dan Granger pada tahun 1987 mensyaratkan bahwa $e_{t}$ haruslah stasioner pada $\mathrm{I}(0)$ untuk dapat menghasilkan keseimbangan jangka panjang(Ginting, 2010). Pada penelitian ini uji kointegrasi dilakukan dengan menggunakan metode Bound Testing Cointegration dengan pendekatan ARDL yang diperkenalkan oleh(Pesaran \& Shin, 2001). Metode tersebut dilakukan dengan cara membandingkan nilai F-statistik hitung dengan nilai krisis. Apabila nilai F-statistik berad dibawah lower bound, maka dapat disimpulkan bahwa tidak terjadi kointegrasi.Apabila nilai F-statistik berada diatas upper bound, maka dapat disimpulkan terjadi kointegrasi. Namun apabila F-statistik berada diantara lower bound dan upper bound maka hasilnya adalah tidak dapat disimpulkan.

\section{Metode Model ARDL}

Model ARDL (Autoregressive Distributed Lag) adalah model dinamis dalam ekonometrika. Jika kita menggunakan model OLS biasa, kita hanya akan melihat jangka panjang, tapi kalau mengunakan model ARDL dapat melihat pengaruh variabel terikat dan bebas dari waktu ke waktu termasuk pengaruh variabel terikat dari masa lampau terhadap nilai terikat masa sekarang. Sebenarnya model ARDL merupakan gabungan antara model AR (Autoregressive) dan DL (Distributed Lag). Model AR adalah model yang menggunakan satu atau lebih data masa lampau dari variabel terikat diantara variabel bebas(Gujarati \& Porter, 2009). Sedangkan DL adalah model regresi melibatkan data pada waktu sekarang dan waktu masa lampau (lagged) dari variabel bebas(Gujarati \& Porter, 2009).

Metode ARDL terdapatestimasi model regresi linear dalam menganalisis hubungan jangka panjang yang melibatkan adanya uji kointegrasi diantara variabel-variabel time series. Metode ARDL memiliki beberapa kelebihan dalam operasionalnya yaitu dapa digunakan pada data short series dan tidak membutuhkan klasifikasi 
praestimasi variabel sehingga dapat dilakukan pada variabel $\mathrm{I}(0)$, $\mathrm{I}(1)$ ataupun kombinasi keduanya. Uji kointegrasi dalam metode ini dilakukan dengan membandingkan nilai Fstatistik dengan nilai F-tabel yang telah disusun oleh(Pesaran\& Shin, 2001).

Dengan mengestimasi langkah pertama yang dilakukan dalam pendekatan ARDL Bound test untuk melihat F-statistik yang diperoleh. Fstatistik yang diperoleh akan menjelaskan ada atau tidaknya hubungan jangka panjang antara variabel. Hipotesis dalam uji $\mathrm{F}$ ini sebagai berkut: $\mathrm{H}_{0}=\alpha_{1}=\alpha_{2}=\alpha_{\mathrm{n}}=0$; tidak terdapat hubungan jangka panjang,

$\mathrm{H}_{1}=\alpha_{1} \neq \alpha_{2} \neq \alpha_{\mathrm{n}} \neq 0$; terdapat hubungan jangka panjang,

Jika nilai F-statistik yang diperoleh dari hasil pengujian Bound Test lebih besar dari nilai upper critical value $\mathrm{I}(1)$ maka tolak $\mathrm{H}_{0}$, sehingga dalam model terdapat hubungan jangka panjang atau terdapat kointegrasi, jika nilai F-statistik berada dibawah nilai lower critical value $\mathrm{I}(0)$ maka tidak tolah $\mathrm{H}_{\mathrm{o}}$, sehingga dalam model tidak terdapat hubungan jangka panjang atau tidak terdapat kointegrasi, jika nilai F-statistik berada diantara nilai upper dan lowe critical value maka hasilnya tidak dapat disimpulkan.

Secara umum model ARDL dalam persamaan jangka panjang dapat dituliskan sebagai berikut:

$$
\begin{gathered}
\mathrm{Pe}_{\mathrm{t}}=\alpha_{0}+\alpha_{1} \mathrm{t}+\sum_{\mathrm{i}=1}^{\mathrm{r}} \alpha_{1}+\mathrm{Pe}_{\mathrm{t}-\mathrm{i}}+\sum_{\mathrm{i}=0}^{\mathrm{y}} \alpha_{2} \mathrm{Kr}_{\mathrm{t}-\mathrm{t}} \\
+\sum_{\mathrm{i}=0}^{\mathrm{T}} \alpha_{3} \mathrm{Eks}_{\mathrm{t}-\mathrm{t}}+\mathrm{et}
\end{gathered}
$$

Keterangan:

$$
\begin{array}{ll}
\mathrm{Pe} & =\text { Pertumbuhan ekonomi } \\
\mathrm{Kr} & =\text { Kurs } \\
\mathrm{Eks} & =\text { Ekspor karet remah } \\
\alpha & =\text { Koefisien dinamis jangka }
\end{array}
$$

panjang

et $=$ Standar eror

Pendekatan dengan menggunakan model ARDL mensyaratkan adanya lag seperti yang ada pada persamaan diatas. Menurut(Juanda, 2009) lag dapat didefinisikan sebagai waktu yang diperlukan timbulnya respon (Y) akibat suatu pengaruh (tindakan atau keputusan). Pemilihan lag yang tepat untuk model dapat dipilih menggunakan basis Schawrtz-Bayesian Criteria (SBC), Akaike Information Criteria (AIC), atau menggunakan informasi kriteria yang lain, model yang baik memiliki nilai informasi kriteria yang terkecil. Langkah selanjutnya dalam metode ARDL adalah mengestimasi parameter dalam short run atau jangka pendek.

\section{HASIL PENELITIAN DAN PEMBAHASAN}

\section{Hasil Penelitian}

Hasil Uji ARDL

Uji ARDL bertujuan untuk mengetahui ada tidaknya pengaruh jangka panjang dan jangka pendek antara variabel penelitian digunakan uji-uji sebagai berikut.

\section{Hasil Uji Stasioneritas}

Adapun hasil pengujian sebagai berikut :

\section{Tabel 2}

\section{Uji Unit Root Test Model PP}

\begin{tabular}{|l|l|l|l|}
\hline \multicolumn{1}{|c|}{ Variabel } & \multicolumn{1}{c|}{$\begin{array}{c}\text { Unit } \\
\text { Root }\end{array}$} & Prob PP & Keterangan \\
\hline $\begin{array}{l}\text { Pertumbuhan } \\
\text { ekonomi(Pe) }\end{array}$ & Level & $\mathbf{0 . 0 0 4 5}$ & Stasioner \\
\hline Kurs (Kr) & Level & 0.3332 & Tidak Stasioner \\
\cline { 2 - 5 } & $\begin{array}{l}\text { First } \\
\text { Diff }\end{array}$ & $\mathbf{0 . 0 0 0 1}$ & Stasioner \\
\hline Ekspor (Eks) & Level & 0.2586 & Tidak Stasioner \\
\cline { 2 - 4 } & $\begin{array}{l}\text { First } \\
\text { Diff }\end{array}$ & $\mathbf{0 . 0 0 0 0}$ & Stasioner \\
\hline
\end{tabular}

Sumber: Data Diolah (2019)

Dari Gambar 2 dapat kita lihat Variabel Pertumbuhan Ekonomi (Pe) signifikan atau dikatakan stasioner pada level pada taraf keyakinan $1 \%$, 5\% dan $10 \%$ yang dibuktikan oleh nilai PP pada variabel tingkat pertumbuhan ekonomi dengan critical value pada berbagai tingkat kepercayan (1\%, 5\% dan 10\%),variabel kurs (kr) data stasioner pada first I (1)different,dan ekspor (Eks) data stasioner dan signifikan padafirst I (1) different.Berdasarkan hasil pengujian stasioneritas maka model Auto RegressiveDistributed Lagged (ARDL)merupakan metode yang cocok digunakan dalampenelitian ini. 


\section{Hasil Uji Lag Optimum}

Adapun hasil pengujian sebagai berikut :

Tabel 3

Hasil Uji Lag Optimum

\begin{tabular}{|c|c|c|c|c|c|c|}
\hline \multicolumn{4}{|c|}{ Incuced obstratuss 26} & & & \\
\hline Las & LogL & LR. & FFE & AIC & SC & HQ \\
\hline 1) & -1268.680 & NA & $9.562-26$ & 70.64891 & 70.78087 & 7069497 \\
\hline 1 & $-1194 \leq 10$ & 1318590 & $2.59-25$ & 6702832 & $6755610^{3}$ & 67.21255 \\
\hline 2 & $-1150,401$ & 22.73102 & $1.99 \mathrm{e} 125$ & 66.74449 & 67.66921 & $67.06689^{-}$ \\
\hline 3 & -1171047 & 13.51150 & $2000-25$ & $66.2482^{2}$ & 68.04442 & 67.18539 \\
\hline
\end{tabular}

Sumber: Hasil Olah Data,2019

dilihatbahwa untuk lag 1 terdapat 1 kriteria yaitu Schwarz Information Criterion (SC). Lag 2 terdapat 3 kriteria yaituLikelihood Ratio (LR), Final Prediction Error (FPE) dan Hannan-Quinn Information Criterion (HQ), untuk lag 3 terdapat 1 kriteria yaitu Akaike Information Criterion (AIC). Sehingga dapat disimpulkan bahwa lag 2 ditetapkan sebagai lag yang optimal untuk dipergunakan dalam estimasi terhadap persamaan umum ARDL. Adapun maksud dari lag optimal pada penelitian ini ialah bahwa semua variabel penelitian yang dipergunakan dalam persamaan saling mempengaruhi satu sama lain sampai duaperiode berikutnya. Jadi dapat disimpulkan bahwa reaksi antara satu varibel dengan variabel lainnya terjadi pada 2 tahun berikutnya, hasil yang diperoleh bahwa kurs dan ekspor karet remah dapat mempengaruhi pertumbuhan ekonomi pada lag ke 2. Artinya ketika ketika kurs meningkat maka pertumbuhan ekonomi jugaakan meningkat pada 2 tahun berikutnya, begitu juga dengan variabel ekspor karet remah meningkat maka akan menyebabkan pertumbuhan ekonomi meningkat pada2 tahun berikutnya.

\section{Uji Causalitas Granger}

Adapun hasil pengujian sebagai berikut :

Tabel 4

Hasil Uji Causalitas Granger

\begin{tabular}{|c|c|c|c|}
\hline ful typotess: & Obs & F-Siatistic & Prob. \\
\hline \multicolumn{4}{|c|}{$\begin{array}{llll}\text { KR does no: Grange-C:US } \equiv P E & 37 & 2.69747 & 0.0901\end{array}$} \\
\hline \multicolumn{2}{|l|}{ FE does azt Granger Cause $R$. } & 1.67983 & $0.20<4$ \\
\hline \multicolumn{4}{|c|}{ 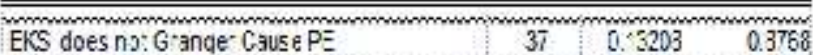 } \\
\hline \multicolumn{2}{|l|}{ FE does not Granger Cause ESS } & 0.06325 & $0.34 \varepsilon 2$ \\
\hline \multicolumn{3}{|c|}{ 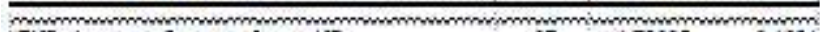 } & $\mathrm{minm}_{0.1881}$ \\
\hline \multicolumn{2}{|l|}{ KR does no: $G$ rnge Cius E EKS } & 5.30477 & 0.0102 \\
\hline
\end{tabular}

Sumber: Hasil Olah Data,2019

Dari tabel 4.4 dapat kita lihat bahwa kurs tidak memiliki hubungan terhadap pertumbuhan ekonomi dengan probabilitasya 0,0901, begitupun sebaliknya pertumbuhan ekonomi tidak memiliki hubungan terhadap kurs dengan probabilitas 0,2024. Varibel ekspor tidak memiliki hubungan terhadap pertumbuhan ekonomi dengan probabilitasnya 0,8768 begitupun sebaliknya pertumbuhan ekonomi tidak memiliki hubungan dengan ekspor yang dapat dibuktikan dengan probabilitasnya sebesar 0,9482. Variabel ekspor tidak memiliki hubungan dengan kurs dilihat dengan probabilitasnya sebesar 0,1881tapi sebaliknya dan varibel kurs memiliki hubungan terhadap ekspor dapat dilihat dengan probabilitasnya 0,0102. Artinya dari dapat disimpulkan bahwa antara varibel penelitian tidak memiliki hubungan timbal balik (granger causality). Hubungan dikatakan terjadi apabila pada tiap-tiap varibel memiliki hubungan 2 arah signifikan pada level $5 \%$ (probability < 0.05 ).

\section{Hasil Kointegrasi Bound Test}

Adapun hasil pengujian yaitu :

\section{Tabel 5}

Hasil Uji kointegrasi

\begin{tabular}{|c|c|c|c|c|}
\hline $\begin{array}{l}\text { typollhesicut } \\
\text { Re e-viss) }\end{array}$ & Lgarvalue & $\begin{array}{l}\text { Trace } \\
\text { Sialisb: }\end{array}$ & $\begin{array}{c}0.66 \\
\text { Critace Velue }\end{array}$ & ratan \\
\hline $\begin{array}{l}\text { Nurit } \\
N \quad \mathrm{i}=11 \\
A-\operatorname{cst} 2\end{array}$ & $\begin{array}{l}0.861095 \\
\text { U188989 } \\
\text { U 10U44. }\end{array}$ & $\begin{array}{l}18.50166 \\
158620 \\
4.1523 \%\end{array}$ & $\begin{array}{l}12.91526 \\
20.8 i=11 \\
12.5<190\end{array}$ & $\begin{array}{l}0.0091 \\
0.8582 \\
0.7225\end{array}$ \\
\hline mentrodes & 2 man Rank & Moximu- & ryalus). & $\ldots .$. \\
\hline $\begin{array}{l}\text { "typothealion } \\
\text { te erfory }\end{array}$ & Figriolins & $\begin{array}{l}m x=y= \\
\text { simath }\end{array}$ & bitios viue & rabs \\
\hline $\begin{array}{l}\text { Nrne } \\
\text { N-nsi }\end{array}$ & $\begin{array}{l}\text { ousiogs" } \\
\text { cisndan } \\
\text { rinkits }\end{array}$ & $\begin{array}{l}373044 \\
75283 \\
1182978\end{array}$ & 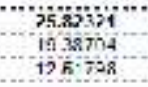 & 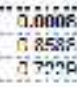 \\
\hline
\end{tabular}

Sumber: Hasil Olah Data,2019

Dari hasil diatas dapat dilihat bahwa, nilai trace statistic yaitu 49.60165 lebih besar dari critical value yang nilainya 42.91525, begitu juga dengan nilai max eige stat sebesar 37.90644 
lebih besar dari critical value yang nilainya 25.82321, jadi dapat disimpulkan dari hasil ter kointegrasi diatas bahwa dalam jangka panjang terdapat kointegrasi di dalam model persamaan tersebut.

Hasil pengujian kointegrasi dengan menggunakan pendekatan bound testdapat dilihat pada tabel 6

Tabel 6

Hasil Uji kointegrasi

\begin{tabular}{|l|r|r|}
\hline Test Statistic & Value & K \\
\hline F-statistic & 8.965744 & 2 \\
\hline \multicolumn{3}{|c|}{ Critical Value Bounds } \\
\hline Significance & I0 Bound & I1 Bound \\
\hline $\mathbf{1 0 \%}$ & 2.63 & 3.35 \\
\hline $\mathbf{5 \%}$ & 3.1 & 3.87 \\
\hline $\mathbf{2 . 5 \%}$ & 3.55 & 4.38 \\
\hline $\mathbf{1 \%}$ & 4.13 & 5 \\
\hline
\end{tabular}

Sumber: Data Diolah, 2019

Berdasarkan tabel 4.5.2 diatas, hasil uji kointegrasi berdasarkan pendekatan Bound testmenunjukkan nilaiF-statistik sebesar 8.965744, yang berarti nilai F-statistik 8.965744 lebih besar dari nilai I0 Bound baik pada tingkat signifikansi $10 \%, 5 \%, 2.5 \%$ dan $1 \%$, maka dapat disimpulkan bahwa terdapat kointegrasi pada variabel-variabel dalam model yang diuji, sehingga adanya keseimbangan jangka pendek dan jangka panjang pada variabel- variabel tersebut.

\section{Hasil Estimasi Model ARDL}

Model ARDL (Autoregressive Distributed Lag) merupakan model dinamis yang dapat melihat pengaruh variabel $\mathrm{X}$ dan $\mathrm{Y}$ dari waktu ke waktu termasuk pengaruh variabel $\mathrm{Y}$ dari masa lampau terhadap nilai Y masa sekarang, atau dengan kata lain dapat melihat hubungan jangka panjang dan jangka pendek.

\section{Hasil Estimasi Jangka Pendek}

Adapun hasil pengujian yaitu :

Tabel 7

Hasil Uji Estimasi Jangka Pendek

\begin{tabular}{|c|c|c|c|c|}
\hline Variable & Coefficient & Std. Error & t-Statistic & Prob.* \\
\hline DDIE -1$)$ & 0.232822 & $0.165: 20$ & 11.405000 & $0.1 \%$ \\
\hline $\operatorname{DDPE}(-2)$ & -0.244557 & 0.161482 & -1.514450 & 0.1407 \\
\hline DDKR. & -0.001717 & 0.00755 & -3.416300 & 0.0019 \\
\hline TDKR (-1) & $00 \min 2=$ & 0700795 & $\pi 912725$ & $\pi \div 697$ \\
\hline DDKR $(-2)$ & 0.0001857 & $0.000 \div 83$ & 1.469035 & 0.1526 \\
\hline DDEKS & $3.4^{4} \mathrm{E}-10$ & $2.74-10$ & 1.255155 & $0.21 \%=$ \\
\hline 0 & $3.99: 810$ & 1.399163 & 4.311015 & uncos \\
\hline
\end{tabular}

Sumber: Hasil Olah Data,2019

Berdasarkan hasil pengujian model jangka pendek dengan ARDL pada Tabel 7di atas mempunyai persamaan sebagai berikut:

$\mathrm{Pe}=5.993847-0.001717 \mathrm{kr}+0.0000000000344 \mathrm{eks}$

Dari estimasi di atas diketahui apabila kurs dan ekspor konstan dalam jangka pendek maka pertumbuhan ekonomi di Indonesia meningkat sebesar 5.993847 persen, apabila kurs meningkat sebesar 1 USD dalam jangka pendek maka pertumbuhan ekonomi di Indonesia akan melemah atau menurun sebesar 0.001717 persen dan apabila ekspor karet remah meningkat sebesar 1 USD dalam jangka pendek maka akan meningkatkan pertumbuhan ekonomi di Indonesia sebesar 0.0000000000344 persen. Dan dari hasil pengujian diatas dapat disimpulkan bahwa variabel kurs dalam jangka pendek berpengaruh negatif dan signifikan terhadap pertumbuhan ekonomi Indonesia dengan probabilitasnya 0.0019 dan variabel ekspor karet remah dalam jangka pendek berpengaruh positif tapi tidak signifikan terhadap pertumbuhan ekonomi Indonesia yaitu dapat dibuktikan dengan probalitasnya melebihi $5 \%$ yaitu 0.2195 .

\section{Hasil Estimasi Jangka Panjang}

Adapun hasil pengujian yaitu :

Tabel 8

Hasil Uji Estimasi Jangka Panjang

\begin{tabular}{|c|r|rr|r|}
\hline \multicolumn{5}{|c|}{ Long Run Coeficients } \\
\hline Variable & Coefficient & Std. Error & t-Statistic & Prob. \\
\hline DDKR & -0.000133 & 0.000156 & -0.858673 & 0.3979 \\
\hline DDEKS & $3.40 E-10$ & $2.58 E-10$ & 1.317723 & 0.1979 \\
\hline C & 5.924323 & 0.843040 & 7.027337 & 0.0030 \\
\hline
\end{tabular}


Berdasarkan hasil pengujian model jangka panjang dengan ARDL pada Tabel 4.6.2di atasmempunyai persamaan sebagai berikut:

\section{$\mathrm{Pe}=5.924329-0.000134 \mathrm{kr}+0.0000000000340 \mathrm{eks}$}

Dari estimasi di atas diketahui apabila kurs dan ekspor konstan dalam jangka panjang maka pertumbuhan ekonomi di Indonesia meningkat sebesar 5.924329 persen, apabila kurs meningkat sebesar 1 USD dalam jangka panjang maka pertumbuhan ekonomi di Indonesia akan melemah atau menurun sebesar 0.000134 persen dan apabila ekspor karet remah meningkat sebesar 1 USD dalam jangka pendek maka akan meningkatkan pertumbuhan ekonomi di Indonesia sebesar 0.0000000000340 persen, dari hasil pengujian diatas dapat disimpulkan bahwa variabel kurs dalam jangka panjang berpengaruh negatif tetapi tidak signifikan terhadap pertumbuhan ekonomi dapat dibuktikan dengan probalitasnya melebihi 5\% yaitu 0.3976 dan variabel ekspor karet remah dalam jangka panjang berpengaruh positif tapi tidak signifikan terhadap pertumbuhan ekonomi dapat dibuktikan dengan probalitasnya melebihi $5 \%$ yaitu 0.1979 .

\section{Pembahasan}

\section{Hubungan Keseimbangan Jangka Pendek Antara Variabel}

Berdasarkan hasil pengujian yang telah dilakukan dapat disimpulkan bahwa variabel kurs dalam jangka pendek berpengaruh negatif dan signifikan terhadap pertumbuhan ekonomiIndonesia. Artinya setiap peningkatan kurs sebesar 1 USD maka dalam jangka pendek berpengaruh negatif terhadap pertumbuhan ekonomiIndonesia, dalam arti lain setiap peningkatan kurs sebesar 1USD maka akan berpengaruh terhadap melemahnya pertumbuhan ekonomidi Indonesia sebesar0.001717 persen, teori ini didukung olehpendapat(Septiawan et al., 2016) hasil dari penelitiannya adalah bahwa kurs berpengaruh signifikan dan negatif terhadap pertumbuhan ekonomi, menunjukkan bahwa pertumbuhan ekonomi berpengaruh terhadap nilai tukar. Apabila kondisi suatu negara mengalami perubahan, maka biasanya diikuti oleh perubahan nilai tukar secara substansional. Kondisi ekonomi yang stabil salah satunya dapat ditunjukkan dengan pertumbuhan ekonomi yang baik.

Variabel ekspor karet remah dalam jangka pendek berpengaruh positif tapi tidak signifikan terhadap pertumbuhan ekonomi Indonesia. Artinya setiap peningkatan ekspor karet remah sebesar 1 USD dalam jangka pendek maka akan mengakibatkan pertumbuhan ekonomi Indonesia meningkat sebesar 0.000000000344 persen.dan sebaliknya setiap penurunan jumlah ekspor karet remah sebesar 1 USD maka dalam jangka panjang akan berpengaruh terhadap melemahnya pertumbuhan ekonomi sebesar 0,0000000000344persen.

Dan teori ini didukung olehpendapat(Hariyani et al., 2016) yang menyatakan bahwaekspor memiliki pengaruh positif dan tidak signifikan terhadap pertumbuhan ekonomi Indonesia dikarenakan oleh ekspor di Indonesia masih bergantung pada impor sebagai bahan baku dan menggunakan tehnologi luar untuk mengelola sumber daya yang ada di dalam negeri.

\section{Hubungan Keseimbangan Jangka Panjang Antara Variabel}

Berdasarkan hasil pengujian yang telah dilakukan dapat disimpulkan bahwa variabel kurs dalam jangka panjang berpengaruh negatif tapi tidak signifikan terhadap pertumbuhan ekonomiIndonesia.Artinya setiap peningkatan kurs sebesar 1 USD maka dalam jangka panjang berpengaruh terhadap melemahnya pertumbuhan ekonomidi Indonesia sebesar0.000134 persen, dan begitupun sebaliknya jika terjadi pelemahan kurs sebesar 1 USD maka dalam jangka panjang akan mengakibatkan pertumbuhan ekonomi menguat sebesar 0.000134 persen.

Dan teori ini didukung olehpendapat(Astuti, 2014)ekspor berpengaruh positif tapi tidak signifikan karena pengaruh jalur nilai tukar terhadap pertumbuhan ekonomi tidak berlangsung seketika. Hal ini dimungkinkan karena dalam jangka pendek maupun panjang banyak transaksi internasional menggunakan hedging (perlindungan 
terhadap nilai tukar) sehingga perubahan nilai tukar tidak mempengaruhi transaksi internasional termasuk ekspor neto.Keterpurukan uang Indonesia terhadap dollar Amerika, didasari atas kebijakan akan kebijakan moneter yang dilakukan oleh pemerintah Amerika. Dimulai kebijakan dinaikkannya suku bunga serta likuiditas dollar Amerika yang diperkecil atau diperketat. Selain kebijakan fiskal Amerika melakukan ekspansif dengan penurunan pajak dan belanja yang meningkat. Ditambah penerapan perang dagang oleh Presiden Amerika kepada Eropa dan China dengan kenaikan tarif barang impor ke Amerika. Dampak dari kebijakan Amerika itu sendiri dirasakan oleh seluruh negara dalam bentuk suku bunga dollar meningkat, arus modal ke seluruh dunia terutama ke negara berkembang dan emerging menurun sehingga terjadi ketidakpastian perdagangan internasional(Sari, 2019).

Variabel ekspor karet remah dalam jangka panjang berpengaruh positif tapi tidak signifikan terhadap pertumbuhan ekonomi Indonesia. Artinya setiap peningkatan ekspor sebesar 1 USD dalam jangka panjang maka akan mengakibatkan pertumbuhan ekonomi Indonesia meningkat sebesar 0.000000000340 persen.dan sebaliknya setiap penurunan jumlah ekspor karet remah sebesar 1 USD maka dalam jangka panjang akan berpengaruh terhadap melemahnya pertumbuhan ekonomi sebesar 0,0000000000340persen.

Dan teori ini didukung olehpendapat (Hariyani et al., 2016) yang menyatakan bahwaekspor memiliki pengaruh positif dan tidak signifikan terhadap pertumbuhan ekonomi di Indonesia dikarenakan oleh ekspor di Indonesia masih bergantung pada impor sebagai bahan baku dan tehnologi masih menggunakan tehnologi luar untuk mengelola sumber daya yang ada di dalam negeri. Dan didukung juga oleh pendapat (Dritsaki \& Stiakakis, 2014)mengatakan bahwa dalam jangka panjang hubungan kausalitas antara ekspor dan pertumbuhan ekonomi berpengaruh positif namun tidak begitu berpengaruh terhadap pertumbuhan ekonomi, hal ini menunjukkan bahwa ada beberapa kendala dalam perluasan ekspor, karena baik kemampuan produksi yang dibatasi atau kurangnya teknologi kontemporer di industri suatu negara.

\section{KESIMPULAN DAN SARAN}

\section{Kesimpulan}

Berdasarkan hasil penelitian dapat diambil kesimpulan antara lain :

1. Dalam model persamaan jangka pendek diketahui bahwa variabel kurs memiliki korelasi negatif dan signifikan terhadap pertumbuhan ekonomoi di Indonesia dan model persamaan jangka panjang diketahui bahwa variabel kurs berpengaruh negatif tapi tidak signifikan terhadap pertumbuhan ekonomi di Indonesia.

2. Dalam model persamaan jangka pendek dan jangka panjang diketahui bahwa variabel ekspor karet remah memiliki korelasi positiftapi tidak signifikan terhadap pertumbuhan ekonomi di Indonesia.

\section{Saran}

Berdasarkan hasil pengolahan data dan dengan segala keterbatasan yang ada dalam penelitian ini terdapat beberapa saran yang dapat diberikan, yaitu

1. Dalam penelitian ini masih jauh dari kata sempurna diharapkan kepada peneliti yang tertarik pada bidang ini disarankan untuk mengambil rentan waktu yang lebih lama dan menambahkan variabel-variabel lainnya, supaya dapat mmberikan hasil yang lebih relevan terhadap Pertumbuhan Ekonomi Indonesia.

2. Bagi peneliti selanjutnya dapat menambahkan variabel lain yang lebih banyak serta data yang digunakan, sehingga hasil yang diperoleh pun lebih akurat dan dapat menjelaskan secara nyata dari pengaruh dan hubungan pertumbuhan ekonomi di Indonesia.

3. Bagi masyarakat semoga melalui penelitian ini dapat mengetahui tentang permasalahan hubungan jangka panjang dan jangka pendek antara kurs dan ekspor karet remah terhadap pertumbuhan ekonomi di Indonesia.

4. Disarankan kepada pemerintah, hendaknya lebih mengkaji lagi tentang segala kebijakan yang diterapkan serta menjadikan pertumbuhan 
ekonomi sebagai tujuan akhir dari prioritas kebijakan di Indonesia. Pemerintah lebih memperhatikan kurs karena melemahnya nilai tukar rupiah terhadap dolar haruslah disikapi dengan sangat baik dan serius baik pemerintah maupun bank sentral. Ekspor karet remah seharusnya dapat diperhatikan lebih serius lagi oleh pemerintah dikarenakan ekspor yang banyak tidak diiringi oleh pendapatan petani karet yang semakin hari semakin murah harganya sehingga berdampak terhadap kesejahteraan petani karet mengingat bahwa karet merupakan salah satu ekspor hasil perkebunan terbesar kedua di indonesia setelah sawit seharusnya dapat memberikan manfaat serta mendorong pertumbuhan ekonomi di Indonesia.

\section{DAFTAR PUSTAKA}

Adiningsih, putra karim Basri, H. N. (2002). Analisis Faktor Faktor Yang Mempengaruhi Kurs. Jurnal Ekonomi Dan Kebijakan Publik.

Astuti, R. D. (2014). Peranan suku bunga, harga aset, dan nilai tukar dalam pertumbuhan ekonomi di indonesia. Jurnal Ekonomi Dan Studi Pembangunan, 15, 135-143.

Dritsaki, C., \& Stiakakis, E. (2014). Foreign Direct Investments, Exports, and Economic Growth in Croatia: A Time Series Analysis. Procedia Economics and Finance, 14, 181-190. https://doi.org/10.1016/s2212-5671(14)00701-1

Ginting, S. (2010). Prosedur Penelitian: Suatu Pendekatan Praktis. Edisi Revisi. Jakarta: PT. Rineka Cipta.

Gujarati, D. ., \& Porter, D. . (2009). Dasar Dasar Ekonometrika (5th ed.). Salemba Empat.

Gujarati, D. N. (2012). Dasar Dasar Ekonomertika. Terjemahan Mangunsong, R.C., Salemba Empat, Buku 2.

Hariyani, H. F., Priyarsono, S. S., \& Asmara, A. (2016). Jurnal Ekonomi dan Kebijakan Pembangunan, hlm. 32-44 Vol 5 No 2. Jurnal Ekonomi Dan Kebijakan Pembangunan, 5(1), 25-44.

Juanda, B. (2009). Metedologi Penelitian Ekonomi Dan Bisnis. IPB Press. Bogor.
Kartikasari, D. (2017). International Journal of Economics and Financial Issues The Effect of Export, Import and Investment to Economic Growth of Riau Islands Indonesia. International Journal of Economics and Financial Issues, 7(4), 663-667. http:www.econjournals.com

Kasmir. (2008). Analisis Laporan Keuangan. PT. Rajagrafindo Persada.

Kuncoro, M. (2007). Metode Kuantitatif: Teori dan Aplikasi Untuk Bisnis dan Ekonomi, Edisi Ketiga. In Jakarta: Erlangga.

Mankiw, N. G. (2003). Teori Makro Ekonomi Terjemahan. In Jakarta: PT Gramedia Pustaka Utama.

Nasution, R. D. R. A. (2009). Volatilitas Nilai Tukar Rill, Instabilitas Ekspor Dan Pertumbuhan Output Indonesia Dalam Rezim Nilai Tukar Mengambang. Jurnal Depok, Universitas Indonesia.

Nizar, M. (2012). Dampak Fluktuasi Harga Minyak Dunia Terhadap Perekonomian Indonesia. Jurnal Depok: Universitas Indonesia.

Pesaran, M., \& Shin. (2001). Bound Testing Approachs To The Analysis of Level Relationship. Cambridge: University Of Cambridge.

Salvatore, D. (2008). Theory And Problem Of Micro Economic Theory (Ahli Bahasa OlehRudi Sitompul (ed.); 3rd ed.). Erlangga.

Sari, D. K. (2019). PERTUMBUHAN EKONOMI DI INDONESIA ( STUDI KASUS ERA JOKOWI - JK ) .

Septiawan, D. A., Hidayat, R. R., \& Sulasmiyati, S. (2016). Pengaruh Minyak Dunia, Inflasi, dan Nilai Tukar Terhadap Pertumbuhan Ekonomi Indonesia ( Studi Pada Tahun 2007 - 2014 ). Jurnal Administrasi Bisnis, 40(2), 130-138. https://www.mendeley.com/catalogue/pengaruhminyak-dunia-inflasi-dan-nilai-tukar-terhadappertumbuhan-ekonomi-indonesia-studi-pada-tahu/

Sugiyono. (2012). Metode Penelitian Pendidikan: Pendekatan Kuantitatif, Kualitatif dan R\&D. In Bandung: Alfabeta.

Sukirno, S. (2000). Pengantar Teori Ekonomi Makro. In Jakarta: PT Raja Grafindo Persada.

Sutawijaya, A. (2010). Pengaruh Ekspor Dan Investasi Terhadap Pertumbuhan Ekonomi Indonesia Tahun 1980-2006. Jurnal Organisasi Dan Manajemen, 6(1), 14-27. 
Tambunan, T. (2003). Perekonomian Indonesia: Beberapa Masalah Penting. In Jakarta: Penerbit Ghalia Indonesia.

Tang, B. (2015). Real exchange rate and economic growth in China: A cointegrated VAR approach. China Economic Review, 34, 293-310. https://doi.org/10.1016/j.chieco.2014.12.002

Widarjono, A. (2007). Ekonometrika: Teori Dan Aplikasi Untuk Ekonomi Dan Bisnis (Ekonisia (ed.)).

Wikipedia. (2019). Badan Pusat Statistik (BPS) Indonesia. www.wikipedia.org.

Yahya, A. H., Mohd, N., \& Syahnur, S. (2015). Analysis of the Export-Base Commodity Supply on the Economic Growth in Aceh, Indonesia. 4(June), 56-67. 